\title{
UJI EFEKTIVITAS BAKTERI ANTAGONIS Pseudomonas flourescens DAN $P$. putida UNTUK MENGENDALIKAN $P$. solanacearum PENYEBAB PENYAKIT LAYU PADA TANAMAN MURBEI
}

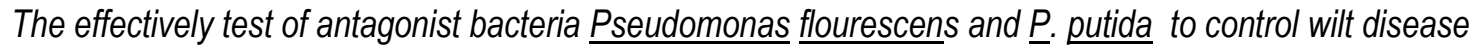 \\ caused by $\underline{P}$. solanacearum on the mulberry
}

Sitti Nuraeni dan Abdul Fattah

\begin{abstract}
Pseudomonas solanacearum is a bacterial agent causing wilt disease on mulberry species and other woody plant in Indonesian. Biological control employing the antagonist bacteria such as $P$. fluorescens and $P$. Putida is a potential method. The aim of the research was to know the effectiveness of $P$. fluorescens and $P$. putida to suppress wilt diseases caused by $P$. solanacearum. The diseases control test with antagonist bacteria was conducted by immersion of root of seedlings in $P$. fluorescens and $P$. putida suspensions before planted in a growth medium inoculated by $P$. solanacearum with the all concentrations were $10^{8} \mathrm{CFU} / \mathrm{ml}$. The following parameters were observed: numbers of leaves, fresh and dry weights of leaves and severity of disease. The results of the effectiveness test showed that antagonist bacteria in the form of mixing of $P$. fluorescens and $P$. putida was the best, because they were capable to suppress wilt disease caused by $P$. solanacearum and increased productivity of mulberry leaves.
\end{abstract}

keywords : antagonist bacteria, biological control, wilt disease

\section{PENDAHULUAN}

Murbei (Morus spp.) adalah salah satu jenis perdu yang merupakan hasil hutan bukan kayu dalam bidang kehutanan Indonesia yang telah lama dibudidayakan. Daun murbei dimanfaatkan sebagai pakan utama ulat sutera (Bombyx mori L). Pemanfaatan lahan pertanaman murbei yang belum optimal khusus di daerah Sulawesi Selatan disebabkan oleh produktivits daun murbei per pohon yang masih rendah. Produktivitas daun murbei yang masih rendah tersebut disebabkan selain karena penanaman jenis tanaman murbei bukan dari jenis yang unggul, kultur teknis pemeliharaan tanaman belum dilakukan sebagaimana mestinya, juga disebabkan adanya serangan berbagai jenis hama dan patogen.

Penyakit penting yang menyerang pertanaman murbei di Sulawesi Selatan antara lain adalah penyakit kanker oleh Erwinia amylovora, penyakit hawar daun oleh $P$. syringae $p v$ mori, penyakit embun tepung oleh Phyllactinia corylea dan penyakit layu bakteri yang disebabkan oleh $P$. solanacearum. Pada tiga sentra pertanaman murbei di Sulawesi Selatan, yaitu Kabupaten Gowa, Soppeng dan Enrekang ditemukan penyakit layu bakteri intensitas serangannya berkisar 330\% (Laike, 1996).

Selain tanaman murbei, penyakit layu yang disebabkan oleh $P$. solanacearum juga dilaporkan menyerang tanaman beberapa tanaman sayursayuran dan beberapa tanaman kehutanan seperti jati (Tectona grandis), cemara laut (Causarina equisetifolia), cemara gunung (C. junghuhniana) dan tusam (Pinus merkusii). Pada uji laboratorium, $P$. solanacearum dapat menyerang semua jenis murbei dengan intesitas serangannya mencapai $100 \%$ (Nuraeni dan Fattah, 2005).

Penyakit layu bakteri yang menyerang tanaman pertanian dan kehutanan hingga kini masih sulit dikendalikan, selain karena bakteri tersebut mempunyai jenis inang yang luas, juga karena belum banyaknya penelitian yang menyangkut pengendaliannya. Upaya pengendalian penyakit ini pada tanaman murbei belum pernah dilakukan, dikarenakan informasi keberadaan penyakit ini belum lengkap, sedangkan upaya pengendalian pada beberapa jenis tanaman pertanian lain telah banyak dilakukan. Pengendalian secara konvensional berupa sanitasi dan pemakaian bahan kimia seperti antibiotik atau bakterisida belum menunjukkan hasil yang memuaskan. 
Tindakan yang lebih efektif untuk pengendalian penyakit layu bakteri adalah tindakan preventif atau pencegahan penyebaran patogen ini melalui tanah (soil borne), yaitu penggunaan agensia pengendali biotik yang berpotensi tinggi menghambat serangan bakteri patogen, mampu beradaptasi dan berkolonisasi pada perakaran tanaman. Salah satu agensia pengendali biotik adalah penggunaan bakteri antagonis yang nonpatogen seperti $P$. fluorescens and $P$. putida. Menurut Rahman (1997), kedua bakteri antagonis ini merupakan bakteri kelompok fluorescent yang juga dapat berfungsi sebagai PGPR (Plant GrowthPromoting Rhizobacteria). Penggunaan kedua bakteri ini dilaporkan telah memberikan hasil yang positif terhadap pertumbuhan dan produksi pada tanaman pertanian.

\section{BAHAN DAN METODE}

Bahan yang digunakan dalam penelitian ini adalah bibit murbei (Morus canya) provenan India, Bakteri Pseudomonas solanacearum, $P$. fluorescens, P. putida, media (NGA, TTC, King's B, mineral, SPA) dan antibiotik (streptomycin dan tetrasiklin).

Prosedur pelaksanaan penelitian ini adalah bibit murbei yang telah tumbuh 65 hari dikeluarkan dari polybag, langsung direndam selama 1 jam dalam gelas ukur yang berisi bakteri antagonis atau antibiotik dengan konsentrasi $3 \%$. Kemudian bibit tersebut ditanam kembali di dalam polybag yang tanahnya telah ditulari bakteri patogen. Jumlah bibit yang dipakai setiap ulangan adalah sebanyak 3 bibit. Jumlah perlakuan adalah sebanyak sembilan yang diulang empat kali disusun dalam rancangan acal lengkap (RAL). Perlakuan yang dicobakan adalah sebagai berikut : T0 : tanaman tanpa perlakuan, $\mathrm{T} 1$ : $P$. solanacearum, T2 : $P$. solanacearum $+P$. fluorescens, T3: $P$. solanacearum $+P$. putida, T4 : $P$. solanacearum $+P$. fluorescens $+P$. pituda, $T 5$ : $P$. fluorescens, T6 : P.putida, T7 : $P$. fluorescens + $P$. putida dan T8: $P$. solanacearum + antibiotik

Parameter untuk intensitas serangan penyakit layu adalah menghitung jumlah daun yang layu, diamati pada setiap interval delapan hari dengan cara melihat gejala yang timbul dan kemudian ditentukan skornya seperti terlihat pada Tabel 1. Untuk produktivitas tanaman murbei diamati adalah jumlah daun, berat basah dan kering daunnya.
Table1. By the way of value/scorings of seedling mulberry condition

\begin{tabular}{lc}
\hline \multicolumn{1}{c}{ seedling mulberry condition } & scorings \\
\hline No symptoms & 0 \\
1 - 2 leaves wilts or yellowing & 1 \\
More than two leaves wilts or yellowing & 2 \\
All the leaves wilt or yellowing & 3 \\
Seedling die & 4 \\
\hline
\end{tabular}

Intensitas serangan dihitung dengan menggunakan rumus (Kelman, 1952 dalam Hutagalung, 1980) sebagai berikut:

$$
I=\frac{\sum(n \times v)}{N \times Z} \times 100 \%
$$

where, $\quad I=$ severity of wilt disease

$\mathrm{n}=$ number of the leaves wilting

$v=$ value/scoring of each seedling

$\mathrm{N}=$ all the leaves investigation

$Z=$ highest value/scoring to used

\section{HASIL DAN PEMBAHASAN}

\section{Perkembangan Penyakit Layu Bakteri}

Penilaian perkembangan penyakit layu bakteri pada tanaman murbei dilihat pada intensitas serangan penyakit pada $8-56$ hari setelah diinokulasi dengan $P$. solanacearum dan bakteri antagonisnya yaitu $P$. fluorescens dan $P$. putida disajkan pada Tabel 2. Data menunjukkan bahwa, pemberian bakteri antagonis $P$. fluorescens dan $P$. putida pada tanaman murbei, baik secara tunggal maupun kombinasi keduanya mampu menekan perkembangan penyakit layu yang disebabkan oleh $P$. solanacearum.

Penggunaan bakteri antagonis mampu menekan penyakit layu pada tanaman murbei, yaitu $P$. fluorescens hingga $43 \%$, P. putida $57 \%$ dan kombinasi keduanya hingga $67 \%$. Kemampuan kedua bakteri antagonis ini juga telah dibuktikan pada percobaan pada tanaman pertanian lain, seperti pada hasil penelitian Shekhawat et al (1992), bahwa secara tunggal $P$. fluorescens dapat menekan $P$. solanacearum pada tanaman kentang sampai $43 \%$ di rumah kaca dan $66 \%$ di lapangan. Begitu pula Rahman (1997) melaporkan, bahwa $P$. fluorescens mampu menekan penyakit layu ini sampai $75 \%$ dan P. putida $65 \%$ serta kombinasi keduanya $80 \%$ di rumah kaca. 
Tablel 2. Tukey's test of severity of disease by $P$. solanacearum after inoculation and to control with $P$. flourescens and $P$. putida at $8-56$ days after inoculatin

\begin{tabular}{lrrrrrrr}
\hline \multirow{2}{*}{ Treatments } & \multicolumn{7}{c}{ Severity of disease days after inoculation (\%) } \\
\cline { 2 - 8 } & \multicolumn{1}{c}{16} & \multicolumn{1}{c}{ 16 } & \multicolumn{1}{c}{32} & \multicolumn{1}{c}{40} & \multicolumn{1}{c}{48} & \multicolumn{1}{c}{56} \\
\hline T0 & 0.00 & 0.00 & 0.00 & 0.00 & 0.00 & 0.00 & $0.00 \mathrm{c}$ \\
T1:Ps & 15.63 & 40.63 & 50.00 & 59.34 & 59.38 & 59.38 & $65.63 \mathrm{a}$ \\
T2:Ps+Pf & 12.50 & 25.00 & 31.25 & 37.50 & 37.50 & 37.50 & $37.50 \mathrm{~b}$ \\
T3:Ps+Pp & 0.00 & 0.00 & 15.63 & 18.75 & 18.75 & 25.00 & $28.13 \mathrm{~b}$ \\
T4:Ps+Pf+Pp & 0.00 & 12.50 & 12.50 & 18.75 & 21,88 & 21.75 & $21.88 \mathrm{bc}$ \\
T5:Pf & 0.00 & 0.00 & 0.00 & 0.00 & 3.13 & 3.13 & $3.13 \mathrm{c}$ \\
T6:Pp & 0.00 & 0.00 & 12.50 & 12.50 & 15.63 & 15.63 & $15.63 \mathrm{c}$ \\
T7:Pf+Pp & 6.25 & 6.25 & 15.63 & 18.75 & 18.75 & 18.75 & $18.75 \mathrm{c}$ \\
T8:Ps+antibiotic & 15.63 & 21.88 & $28 . .13$ & 31.25 & 40.63 & 46.88 & $46.88 \mathrm{ab}$ \\
\hline
\end{tabular}

Remarks : The value in the same column that followed by the same letter is not significantly different at $\alpha 0.05$.

Data Tabel 2 juga memperlihatkan bahwa penggunaan antibiotik dapat pula menekan penyakit layu pada tanaman murbei walaupun kemampuannya menekan hanya $29 \%$ saja. Di Indonesia penggunaan antibiotik streptomycin sulfat dan tetrasiklin dilakukan sejak tahun 1977. untuk mengendalikan penyakit layu oleh bakteri pada tanaman pertanian, namun hasilnya belum memuaskan dan tidak ekonomis (Setiawati dan Hutagalung, 1984 dalam Mahmud, 1985).

Perkembangan penyakit layu pada tanaman murbei pada masing-masing perlakuan dapat dilihat pada Gambar 1. Perkembangan penyakit layu sampai pada hari ke-56 setelah inokulasi menunjukkan rata-rata di bawah $40 \%$ dengan penggunaan bakteri antagonis sebagai tindakan preventif dan cenderung penyakit tersebut tidak berkembang lagi.

Munculnya gejala penyakit layu pada perlakuan $\mathrm{T} 5, \mathrm{~T} 6$ dan $\mathrm{T} 7$ atau perlakuan tanpa inokulasi $P$. solanacearum diduga karena patogen tersebut lebih dahulu telah berada dalam jaringan tanaman akibat terbawa melalui stek. Menurut Sinha (1985), salah satu sumber inokulum untuk untuk penyebaran $P$. solanacearum adalah melalui bibit atau bahan tanaman. Persley (1985) menambahkan pula, bahwa sumber infeksi yang paling sulit dikontrol adalah melalui bahan tanaman secara vegetatif karena penyebarannya dapat lebih luas dari satu tempat ke tempat lainnya, dari satu musim ke musim berikutnya dengan infeksi laten (symptomless carier).

\section{Produktivitas daun murbei}

Produktivitas daun murbei yang diuji dapat dinilai dari jumlah helaian daun yang dihasilkan, berat basah dan berat kering daunnya yang disajikan pada Gambar 2. Pemberian bakteri antagonis dapat meningkatkan produktivitas tanaman murbei baik dari jumlah daun yang

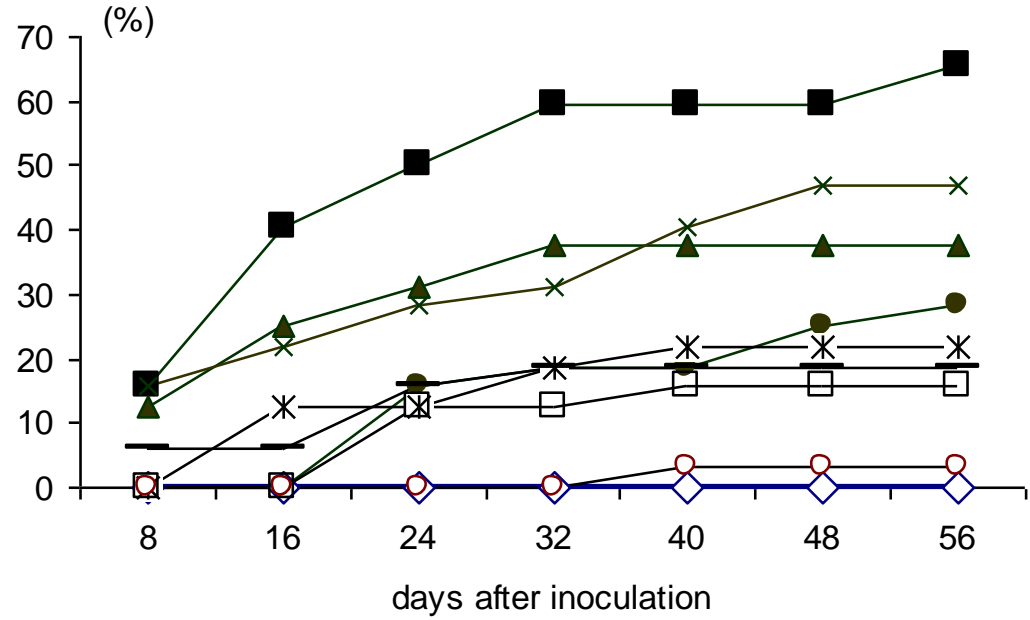

Figure 1. Growth of bacteria wilt disease on mulberry after inoculation.

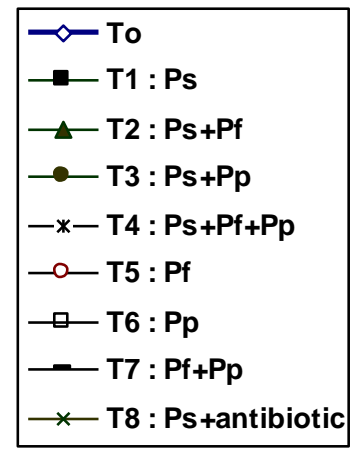

Jurnal Perennial, 3(2) : 44-48 
dihasilkan, juga berat basah dan kering daunnya. Penggunaan dengan mengkombinasikan keduanya (T7/P. fluorescens dan P. putida) dapat meningkatkan jumlah daun sebesar $28 \%$ dibandingkan dengan murbei tanpa perlakuan (T0), sedangkan untuk berat basah dan kering daun meningkat masing-masing $6 \%$ dan $30 \%$. Menurut Aspiras dan Cruz (1985), penggunaan bakteri antagonis $P$. fluorescens dan $P$. putida dapat meningkatkan hasil panen $5-33 \%$.

Peranan bakteri antagonis selain dapat menekan penyakit tanaman juga berperan dalam memacu pertumbuhan tanaman karena bakteri ini termasuk dalam kelompok PGPR (Plant GrowthPromoting Rhizobacteria). PGPR membantu meningkatkan hasil panen tanaman karena aktivitasnya membantu melarutkan bahan anorganik dalam tanah yang dapat digunakan tanaman untuk pertumbuhanya. Sejumlah bakteri PGPR termasuk P. fluorescens dan P. putida dapat memacu pertumbuhan tanaman dengan cara melarutkan fosfat (Defago, 1992; Stefania, 1998). Selain itu bakteri antagonis tersebut dapat mengikat $\mathrm{N}_{2}$ dalam kondisi tanpa simbiosis, memproduksi hormon tumbuh IAA (3-indol acetid acid) dan efektivitasnya dapat ditingkatkan dengan pencampuran PGPR ini dengan PGPR lainnya atau mikroorganisme yang bermanfaat lainnya (Defago, 1992). Menurut Kwong dan Huang (1977), sifat yang dapat melarutkan fosfat yang dimiliki oleh $P$. fluorescens dan $P$. putida sangat bermanfaat terutama pada tanah-tanah masam, karena pada tanah tersebut $\mathrm{P}$ terikat oleh $\mathrm{Al}, \mathrm{Fe}$ atau $\mathrm{Mn}$ sehingga sukar larut.

\section{KESIMPULAN}

Hasil yang terbaik pada uji efektivitas bakteri antagonis pada tanaman murbei adalah dengan cara pencampuran $P$. fluorescens dan $P$. putida karena dapat menekan penyakit layu $P$. solanacearum sampai $67 \%$ dan meningkatkan produktivitas daun murbei sampai $30 \%$.

\section{DAFTAR PUSTAKA}

Aspiras, R.B. and A.R. de la Cruz. 1985. Potential biological control of bacterial wilt in tomato and potato with Bacillus polymyxa FU6 and Pseudomonas fluorescens. In: Bacterial wilt disease in Asian and South Pasific. Proc. Int. Workshop at PCARRD [Persley, G.J. (ed.)]. Australian Centre International Agricultural Research (ACIAR), Los Banos. No. 13: 89-92.

Defago, G. 1992. Plant Growth-Promoting Rhizobacteria, current status. In: 'Plant pathogenic bacteria" [M. Lemmattre, $S$. Freigoun, K. Rudolph and J.G. Swings (eds.)] h 891-894. INRA Route de st Cyr, Versailles, France.

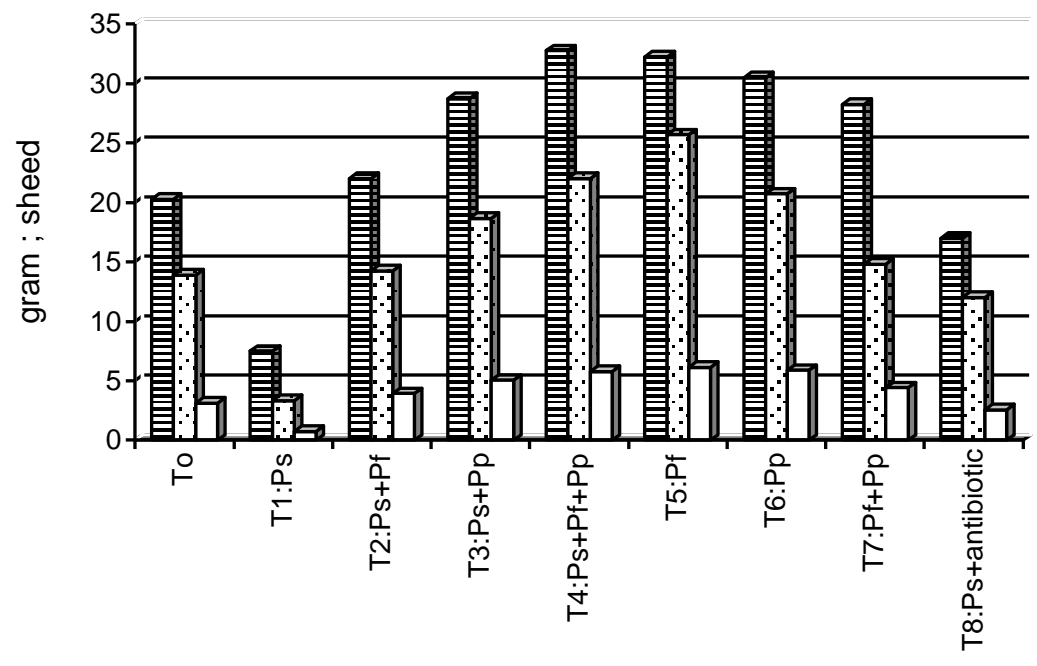

目 Number of leaves $\square$ Fresh weigth of leavas $\square$ Dry weight of leaves

Figure 2. Productivity of mulberry with the number of leaves, fresh and dry weight of leaves. 
Hutagalung, L. 1980. Beberapa aspek penularan bakteri layu Pseudomonas solanacearum E.F. Smith. melalui umbi kentang dan kemungkinan penanggulangannya. Tesis Magister Fakultas Pascasarjana Institut Pertanian Bogor. Bogor.

Kwong, K.F. and P.M. Huang. 1977. Surface reactivity of aluminium hydroxides precipitated in the presence of low molecular weight organic acid soil. Sci. Sos. Am. J. 43: 1107-1113.

Laike. 1996. Inventarisasi dan identifikasi penyakit pada tanaman murbei (Morus spp) di Sulawesi Selatan. Fakultas Pertanian dan Kehutanan Universitas Hasanuddin. Ujung Pandang. $71 \mathrm{~h}$.

Mahmud, M. 1985. Bacterial wilt in Indonesia. In: Bacterial wilt disease in Asian and South Pasific". Proc. Int. Workshop at PCARRD [Persley, G.J. (ed.)]. Australian Centre International Agricultural Research (ACIAR), Los Banos. No. 13: 126-143.

Nuraeni, S dan A. Fattah. 2005. Karakteristik Pseudomonas solanacearum E.F. Smith Bakteri Penyakit Layu pada Tanama Murbei (Morus Spp.). Majalah Ilmiah Agriplus (terakreditasi) Vol. 15. Fakultas Pertanian Universitas Haluoleo, Kendari. Hal 117-180.

Persley. G.J. 1985. Ecology of Pseudomonas solanacearum, the causal agent of bacterial wilt. In: Bacterial wilt disease in Asian and South Pasific". Proc. Int. Workshop at

Diterima : 22 April 2007

\section{Sitti Nuraeni}

Fakultas Pertanian, Universitas Haluoleo

Kampus Bumi Tri Dharma, Kendari, Indonesia

e_mail: enychiko@yahoo.com

\section{Abdul Fattah}

Balai Pengkajian Teknologi Pertanian Sulawesi Selatan JI. Perintis Kemerdekaan Km. 17. Sudiang, Indonesia
PCARRD [Persley, G.J. (ed.)]. Australian Centre International Agricultural Research (ACIAR), Los Banos. No. 13: 126-143.

Rahman, R. 1997. Uji efektivitas bakteri rhizofer (Group Fluorescent Pseudomonads) sebagai Plant Growth-Promoting Rhizobacteria (PGPR) dan penekanannya terhadap penyakit layu (Pseudomonas solanacearum) pada tanaman kentang (Solanum tuberosum). Fakultas Pertanian dan Kehutanan Universitas Hasanuddin. Ujung Pandang. 56p.

Shekhawat, G.S; S.K. Chakrabarti; V. Kishore; V. Sunaina and A.V. Gadewar. 1992. Possibilities of biological management of potato bacterial wilt with strain of Bacillus $s p$, $B$. subtilis, Pseudomonas fluorescens and Actinomycetes. Australian Centre of International Agricultural Research (ACIAR) Proc., Los Banos. No. 126-143.

Sinha, S.K. 1985. Bacterial wilt in India. In: Bacterial wilt disease in Asian and South Pasific". Proc. Int. Workshop at PCARRD [Persley, G.J. (ed.)]. Australian Centre International Agricultural Research (ACIAR), Los Banos. No. 13: 144-153.

Stefania, K. 1998. Identifikasi bakteri rhizosphere kelompok fluorescens dan uji efektivitas dalam menekan penyakit layu (Fusarium oxysforum f. sp. vasintectum) pada tanaman kapas. Fakultas Pertanian dan Kehutanan Universitas Hasanuddin. Ujung Pandang. 77p. 